\title{
KAJIAN YURIDIS PERJANJIAN PENGELOLAAN KOLAM RENANG LANGEN TIRTA KEMBAR ANTARA PEMERINTAH KABUPATEN BANYUMAS DENGAN PT GRAHA CIPTA GUNA
}

\author{
Pangestika Rizki Utami \\ Magister Ilmu Hukum Fakultas Hukum Universitas Jenderal Soedirman \\ Email: pangestikarizki@ymail.com
}

\begin{abstract}
Management Agreement Langen Tirta Kembar swimming pool is a form the government of Banyumas in order to improve the optimization of the utilization of the asset management region. Management agreement has been agreed on 25 July 1988, during the management period of 30 (thirty) years. But since 25 June 2007 Langen Tirta Kembar Swimmingpool closed due to poor water supply problems. This research is to analyze the construction for management agreement and also to analyze the problem solving of Management Agreement of Langen Tirta Kembar Swimmingpool between the Government of Banyumas Regency and PT Graha Cipta Guna. This research is normative legal with conceptual and analytical approach. It is descriptive specification. This is from Center for Scientific Information Faculty of Law Jenderal Soedirman University, Library of Jenderal Soedirman University, The Government of Banyumas regency, PT Graha Cipta Guna, and The law court of Purwokerto. This legal materials sources by primary legal materials, secondary, and tertiary. The method collection of legal materials by library study. Presentment method of legal materials by descriptive-narrative. Analysis of legal materials with descriptive qualitative method.
\end{abstract}

Keywords : Agreement, Management of asset region

\begin{abstract}
Abstrak
Perjanjian Pengelolaan Kolam Renang Langen Tirta Kembar merupakan upaya Pemerintah Kabupaten Banyumas dalam rangka meningkatkan optimalisasi terhadap pemanfaatan pengelolaan aset daerah. Perjanjian pengelolaan telah disepakati pada tanggal 25 Juli 1988, jangka waktu pengelolaan selama 30 (tiga puluh) tahun. Namun sejak tanggal 25 Juni Tahun 2007 Kolam Renang Langen Tirta Kembar ditutup karena permasalahan suplai air yang buruk. Penelitian ini bertujuan untuk menganalisis konstruksi hukum dan untuk menganalisis penyelesaian masalah Perjanjian Pengelolaan Kolam Renang Langen Tirta Kembar antara Pemerintah Kabupaten Banyumas dengan PT Graha Cipta Guna. Penelitian ini adalah penelitian yuridis normatif, dengan pendekatan konsepsional dan pendekatan analisis. Spesifikasi penelitian ini merupakan penelitian deskriptif. Penelitian dilakukan di Pusat Informasi IImiah Fakultas Hukum Universitas Jendral Soedirman, Perpustakaan Universitas Jenderal Soedirman, Pemerintah Kabupaten Banyumas, PT Graha Cipta Guna, dan Pengadilan Negeri Purwokerto. Sumber bahan hukum yang digunakan yaitu bahan hukum primer, sekunder dan tersier. Metode pengumpuluan bahan hukum dengan studi kepustakaan. Penyajian bahan hukum dengan metode deskriptif-naratif. Metode Analisis bahan hukum dengan metode deskriptif kualitatif.
\end{abstract}

Kata Kunci : Perjanjian, Pengelolaan Barang Milik Daerah

\section{PENDAHULUAN}

Pemerintah dalam penyelenggaraan kehidupan berbangsa memiliki tugas pokok untuk memajukan kesejahteraan umum yang berkeadilan sosial bagi seluruh rakyat Indonesia.
Selaras dengan kemajuan zaman kebutuhan masyarakat dari masa ke masa terus meningkat dan pelayanan yang selama ini diberikan oleh pemerintah perlu terus disempurnakan untuk mengarah kepada perbaikan demi memenuhi 
dan memuaskan kebutuhan yang ada dalam masyarakat. Dalam rangka penyediaan infrastruktur publik, Pemerintah dapat melakukan tindakan hukum perdata yang dalam hal ini adalah pengadaan barang dan jasa pemerintah. Di lain pihak, Pemerintah dapat pula bekerjasama dengan sektor swasta untuk mengelola aset milik pemerintah baik pusat maupun daerah untuk mengoptimalkan pemanfaatan aset tersebut bagi kepentingan masyarakat.

Negara dalam kapasitasnya sebagai lembaga yang secara sah merepresentasi agar fungsi negara dapat dijelmakan secara konkrit , pemerintah memiliki dual function, yaitu sebagai lembaga hukum publik maupun sebagai lembaga hukum privat. Pemerintah sebagai lembaga hukum publik bertindak merealisasikan tugas hukum publik negara berdasarkan aturan-aturan hukum publik. Sedangkan Pemerintah sebagai lembaga hukum privat berkedudukan hukum seperti subyek hukum privat (natuurlijk/rechtpersoon), bertindak atas dasar hukum privat dan mengikatkan diri pada konsekuensi-konsekuensi hukum privat yang timbul sebagai akibat perbuatan hukumnya. ${ }^{1}$

Pengelolaan barang milik daerah merupakan bagian dari pengelolaan keuangan daerah. Selain itu, barang milik daerah merupakan salah satu unsur penting dalam rangka penyelenggaran pemerintahan dan pelayanan kepada masyarakat. Oleh karena itu, tentu saja pengelolaan barang milik daerah yang baik akan mencerminkan pengelolaan keuangan daerah yang baik. ${ }^{2}$ Sebagai wujud aktualisasi dari upaya
Pemerintah Kabupaten Banyumas dalam rangka meningkatkan optimalisasi terhadap pemanfaatan pengelolaan aset daerah, Pemerintah Daerah Kabupaten Banyumas mengadakan perjanjian kerjasama dengan PT Graha Cipta Guna Purwokerto tertanggal 15 Desember 1993 tentang Perjanjian Pengelolaan Kolam Renang Langen Tirta Kembar. Dengan adanya perjanjian maka timbul adanya hubungan hukum antara Pemerintah Daerah Kabupaten Banyumas dengan PT Graha Cipta Guna Purwokerto, yaitu hubungan antara dua pihak yang mempunyai akibat hukum.

Para pihak dalam perjanjian, pada dasarnya setiap orang dapat melaksanakan perjanjian dengan siapa saja yang dikehendaki sepanjang orang tersebut tidak dilarang oleh undang-undang untuk melakukkan perjanjian. Subjek hukum adalah setiap pihak yang menjadi pendukung hak dan kewajiban dalam melakukan hubungan hukum. Subjek hukum berhak atas hak-hak subjektif dan pelaku dalam hukum objektif.Manusia adalah pendukung hak dan kewajiban, selain manusia masih ada subjek hukum lainnya yaitu segala sesuatu yang menurut hukum dapat mempunyai hak dan kewajiban, yaitu Badan Hukum (rechtpersoon). ${ }^{3}$ Subjek hukum yang melakukan perjanjian tersebut adalah Badan Hukum, yaitu Pemerintah Kabupaten Banyumas yang merupakan Badan Hukum Publik dan PT Graha Cipta Guna yang merupakan Badan Hukum Privat. Dalam Perjanjian tersebut Pemerintah Kabupaten Banyumas mempunyai Kewajiban menyediakan kolam

3 Chidir Ali, 2014, Badan Hukum, Bandung : Alumni, hlm 46
W.Riawan Tjandra, 2014,Hukum Sarana Pemerintahan,
Yogyakarta : Cahaya Atma Pustaka, Yogyakarta,hlm 95
Oktavia Ester Pangaribuan dan Sumini Widyaiswara
Muda, 2010, Modul Pokok-pokok Pengelolaan Barang
Milik Daerah, Pusdiklat Kekayaan Negara dan

Perimbangan Keuangan, tanpa kota, hlm 8 
renang dan memberikan hak pengelolaan kepada PT Graha Cipta Guna dan menerima hak mendapatkan sejumlah uang setiap bulan dari PT Graha Cipta Guna.Kewajiban PT Graha Cipta Guna adalah mengelola Kolam Renang Langen Tirta Kembar dan menerima hak pengelolaan atas Kolam Renang Langen Tirta Kembar.

Perjanjian yang sah artinya adalah persetujuan yang memenuhi syarat-syarat yang telah ditentukan oleh undang-undang, sehingga ia diakui oleh hukum. ${ }^{4}$ Suatu Perjanjian yang paling penting adalah isinya, keterkaitan para pihak dalam perjanjian adalah keterkaitan pada isi perjanjian, padahal isinya ditentukan atau dalam hal-hal tertentu dianggap ditentukan oleh para pihak sendiri. Karena isinya ditentukan sendiri maka orang sebenarnya terikat pada janjinya sendiri, janji yang diberikan para pihak lain dalam perjanjian. Jadi orang terikat bukan karena ia menghendaki tetapi karena ia memberikan janjinya. ${ }^{5}$

Istilah hukum perjanjian dalam bahasa inggris disebut dengan istilah "contract", yang dalam praktik sering dianggap sama dengan istilah "perjanjian". Akan tetapi pemakaian istilah hukum kontrak dewasa ini memberikan penekananpenekanan terhadap hal-hal perjanjianperjanjian dalam bidang bisnis, perjanjian internasional, multinasional, atau perjanjian dengan perusahaan-perusahaan multi nasional, dan perjanjianperjanjian yang prestasinya dilakukan oleh kedua belah pihak. ${ }^{6}$

Perjanjian yang dibuat oleh pemerintah daerah dengan investor yang ada dalam ranah privat ternyata terkait dengan ketentuanketentuan publik sehingga jelas terlihat bahwa

4 Abdul Kadir Muhammad, 1982, Hukum Perikatan , Bandung: Alumni, hlm 88

5 J.Satrio, 2001, Hukum Perikatan, Perikatan Yang Lahir Dari Perjanjian Buku II, Bandung : Citra Aditya Bakti, hlm 145 hubungan hukum tersebut menampakkan karakter yang berbeda dengan kontrak komersial pada umumnya. Kontrak seperti ini jamak disebut sebagai Kontrak Pemerintah (Government Contract) yang disinyalir berdiri diantara hukum privat dan publik. Surat Perjanjian antara Pemerintah Kabupaten Banyumas dengan PT Graha Cipta Guna tertanggal 15 Desember 1993 tentang Perjanjian Pengelolaan Kolam Renang Langen Tirta Kembar, menyebutkan bahwa Djoko Sudantoko, Bupati Kepala Daerah Kabupaten Banyumas, dalam perjanjian ini sebagai PIHAK PERTAMA dan Made Widiana, Direktur PT Graha Cipta Guna Purwokerto sebagai PIHAK KEDUA. Perjanjian tersebut berlaku selama 30 (tiga puluh) tahun, terhitung sejak tanggal 25 Juli 1988, oleh karena itu perjanjian tersebut berlaku hingga tanggal 24 Juli 2018. Pada Tahun 2007 terdapat permasalahan mengenai kualitas air kolam renang yang tidak baik dan akhirnya Kolam Renang Langen Tirta Kembar ditutup sementara, sejak tanggal 1 Juli 2007.

PIHAK PERTAMA dan PIHAK KEDUA telah sepakat mengadakan Perjanjian PengeIolaan Kolam Renang Langen Tirta Kembar milik PIHAK PERTAMA. PIHAK PERTAMA memberikan ijin kepada PIHAK KEDUA dan karena itu PIHAK KEDUA memperoleh ijin dari PIHAK PERTAMA atas biaya PIHAK KEDUA untuk mengelola bangunan kolam renang langen tirta kembar. PIHAK PERTAMA mempunyai kewajiban menyerahkan Kolam Renang Langen Tirta Kembar pada PIHAK KEDUA, PIHAK PERTAMA mempunyai hak menerima sejumlah

6 Munir Fuady,2014, Konsep Hukum Perdata, Jakarta : Raja Grafindo Persada, hlm 180 
uang dari hasil Pengelolaan Kolam Renang Langen Tirta Kembar tersebut. PIHAK KEDUA berkewajiban menyetorkan uang tunai ke Kas Pemerintah Kabupaten Banyumas sebesar $\$ 1.350$ (seribu tiga ratus lima puluh US dollar) setiap bulan, paling lambat setiap tanggal 10 bulan berikutnya atau melalui Dinas Pendapatan Daerah Kabupaten Banyumas. Adanya Adendum pada tanggal 5 Febuari 2001, bahwa dengan adanya fluktuasi nilai dollar yang tidak menentu, ketentuan mengenai penyetoran uang tunai ke Kas Pemerintah Kabupaten Banyumas dirubah menjadi Rp 10.000.000,- (Sepuluh Juta Rupiah) setiap bulan, paling lambat setiap tanggal 10 bulan berikutnya melalui Dinas Pendapatan Daerah Kabupaten Banyumas sebagai pembayaran atas kontribusi hasil pengelolaan kolam renang, retribusi pemakaian tanah milik Pemerintah Daerah, Pajak Reklame dan Pajak Hiburan.

Permasalahan pada perjanjian yang dibuat oleh Pemerintah Kabupaten Banyumas dengan PT Graha Cipta Guna maka diperlukan adanya penyelesaian permasalahan tersebut, sebelum menganalisis penyelesaian permasalahan tersebut maka harus dikonstruksikan terlebih dahulu Perjanjian Pengelolaan tersebut termasuk dalam jenis perjanjian bernama atau tidak bernama.

\section{METODE PENELITIAN}

Tipe penelitian yang digunakan dalam penelitian ini adalah yuridis normatif atau penelitian hukum yang hanya meneliti bahan pustaka sehingga disebut juga penelitian hukum

7 Soerjono Soekanto dan Sri Mamudji, 2007, Penelitian Hukum Normatif, Jakarta : PT Raja Grafindo Persada, hlm 14

8 Peter Mahmud Marzuki, 2005, Penelitian Hukum Normatif, Jakarta : Kencana, hlm 137 kepustakaan. ${ }^{7}$ Metode Pendekatan Konsepsional merupakan pendekatan yang menggunakan pandangan dan doktrin dari ilmu hukum dalam mengkonsepsikan permasalahan hukum yang tidak diatur dalam peraturan hukum yang ada. ${ }^{8}$ Pendekatan Analisis merupakan pendekatan dengan menganalisis bahan hukum untuk mengetahui makna yang dikandung oleh istilahistilah yang digunakan dalam aturan perundangundangan secara konsepsional. ${ }^{9}$

\section{PEMBAHASAN}

\section{Konstruksi Hukum Perjanjian}

Menurut Satjipto Rahardjo, yang dimaksud dengan konstruksi hukum adalah konsep atau pengertian hukum (pengertian tertentu dalam konteks berfikir secara hukum) yang secara sadar dipikirkan benar, diciptakan dan dipakai untuk satu tujuan. ${ }^{10}$

Paul Shcholten mengajukan tiga syarat yang harus dipenuhi untuk melakukan suatu konstruksi hukum, yaitu :

a. Konstruksi harus meliputi materi positif, artinya tindakan konstruksi harus didasarkan pada hal-hal yang sifatnya pokok dan aturan hukum yang sedang berlaku untuk saat ini.

b. Tidak ada pertentangan di dalamnya artinya bahwa ilmu hukum, dalil abstrak mengenai hukum dan ringkasannya dalam suatu pengertian menuntut kesatuan logis.

c. Harus memenuhi syarat estetis artinya manusia membutuhkan sesuatu yang sederhana, jelas dan mudah dimengerti, begitu juga ilmu hukum yang membutuhkan penggambaran yang jelas, disamping itu konstruksi harus
9 Johnny Ibrahim, 2005, Teori dan Metodelogi Penelitian Hukum Normatif, Malang: Bayumedia,hlm 310

10 Satjipto Rahardjo, 1986, IImu Hukum, Bandung : Alumni, hlm 275-276 
juga berguna bagi tuntutan kepastian dan keadilan. ${ }^{11}$

Prinsip dasar kegiatan mengkonstruksi tersebut akan dijadikan dalam mengkonstruksikan perjanjian pengelolaan antara Pemerintah Kabupaten Banyumas dengan PT Graha Cipta Guna. Hal pertama yang perlu dipastikan adalah hal tertentu dan kausa atau sebab yang halal. Maka dari itu perlu dibahas mengenai syarat sahnya perjanjian pengelolaan kolam renang langen tirta kembar antara Pemerintah Kabupaten Banyumas dengan PT Graha Cipta Guna. Bahwa syarat sahnya perjanjian ada dalam Pasal 1320 KUH Perdata ada 4 syarat yaitu :

\section{Sepakat mereka yang mengikatkan dirinya}

Sepakat mengandung arti bahwa para pihak dalam perjanjian telah ada persesuaian kemauan atau saling menyetujui kehendak masing-masing. Apa yang dikehendaki oleh para pihak yang satu, yang dikehendaki oleh pihak yang lain. Mereka menghendaki sesuatu yang sama secara timbal balik. ${ }^{12}$

Menurut Subekti, bahwa perjanjian perjanjian itu pada umumnya adalah konsensuil. Adakalanya undang-undang menetapkan bahwa, untuk sahnya suatu perjanjian diharuskan perjanjian itu diadakan secara tertulis atau dengan akta notaris, tetapi hal yang demikian itu merupakan suatu kekecualian. Yang lazim, apabila sudah tercapai kesepakatan mengenai hal-hal pokok dari perjanjian tersebut. ${ }^{13}$

Berdasarkan hasil penelitian, antara $\mathrm{Pe}$ merintah Kabupaten Banyumas dengan PT

11 Paul Scholten, Penerjemah Siti Soemantri Hartono, 1992 Mr. C. Asser, Penuntun dalam mempelajari hukum perdata belanda, bagian umum, Yogyakarta : Gajah Mada University Press, hlm 67
Graha Cipta Guna telah sepakat untuk mengadakan perjanjian sehingga syarat sahnya perjanjian tentang kesepakatan terpenuhi yaitu tertuang pada Surat Perjanjian Pengelolaan Kolam Renang Langen Tirta Kembar Nomor 20 Tahun 1993, berupa hak untuk mengelola kolam renang langen tirta kembar milik Pemerintah Kabupaten Banyumas.

\section{Kecakapan untuk membuat suatu perjanjian}

Syarat kedua adalah kecakapan, dalam arti orang yang membuat perjanjian harus cakap menurut hukum. Pada asanya setiap orang yang sudah dewasa dan sehat pikirannya adalah cakap menurut hukum. Dalam Pasal 1329 KUH Perdata menentukan bahwa : Setiap orang adalah cakap untuk membuat perikatan-perikatan, jika ia oleh undang-undang tidak dinyatakan tidak cakap.

Berdasarkan dari hasil penelitian, subjek hukum dalam hal ini adalah Pemerintah Kabupaten Banyumas yang merupakan Badan Hukum Publik dan PT Graha Cipta Guna yang merupakan badan hukum privat yang dibentuk secara yuridis, dengan demikian PT Graha Cipta Guna telah masuk dalam kriteria Badan Hukum Privat, maka menurut teori orgaan sebagaimana telah dijelaskan diatas, syarat subjek hukum yaitu kecakapan telah terpenuhi.

\section{Suatu Hal Tertentu}

Suatu hal tertentu merupakan pokok dari kedua belah atau disebut juga prestasi. Dalam perjanjian tentang suatu hal atau objek tertentu harus disebutkan dengan tegas dan jelas atau prestasi serta kontraprestasi apa dan bagaimana

\footnotetext{
12 R. Subekti, 1987, Hukum Perjanjian, Jakarta : Intermasa, hlm 17

13 Ibid., hlm 15
} 
harus dilaksanakan oleh masing-masing pihak. Prestasi itu harus tertentu atau dapat ditentukan, sedangkan untuk mengatakan tertentu dan dapat ditentukan harus ada jenis dari prestasi itu sendiri.

Berdasarkan hasil penelitian dapat dideskripsikan bahwa suatu hal atau prestasi dan kontraprestasinya adalah tertentu hal ini dapat dilihat dari isi perjanjiannya :

Pemerintah Kabupaten Banyumas memberikan hak kepada PT Graha Cipta Guna untuk mengelola kolam renang langen tirta kembar. Dan sebagai kontraprestasi PT Graha Cipta Guna harus mengelola kolam renang langen tirta kembar serta memberikan uang tunai setiap bulan pada Kas Pemerintah sebesar Rp 10.000.000,- (sepuluh juta rupiah) melalu Dinas Pendapatan Pengelolaan Keuangan dan Aset Daerah Kabupaten Banyumas paling lambat setiap tanggal 10 setiap bulan. Apabila terjadi keterlambatan pembayaran maka dikenakan denda sebesar $1 \%$ (satu persen) per hari.

Berdasarkan pada hasil penelitian, barang yang menjadi objek kontrak juga tertentu yaitu berbentuk Bangunan Kolam Renang Langen Tirta Kembar yang akan dikelola selama 30 (tiga puluh) Tahun.

\section{Suatu Sebab yang Halal}

Sebab atau kausa yang halal dalam syarat ke 4 (empat) Pasal 1320 KUH Perdata adalah isi dari perjanjian itu sendiri yaitu tujuan yang ingin dicapai kedua belah pihak. Suatu kausa atau sebab yang halal merupakan syarat yang keempat atau terakhir untuk sahnya perjanjian. Melihat ketentuan dalam Pasal $1335 \mathrm{KUH}$ Perdata menyatakan bahwa suatu kontrak tanpa sebab atau yang telah dibuat karena suatu sebab yang palsu atau terlarang, tidak mempunyai kekuatan hukum. Selanjutnya dalam Pasal 1337 KUH Perdata menentukan bahwa suatu sebab adalah terlarang apabila dilarang oleh undangundang atau apabila berlawanan dengan kesusilaan atau ketertiban umum. Apabila sebab atau kausa bertentangan dengan apa yang tersebut diatas, maka persetujuan itu batal demi hukum.

Berdasarkan hasil penelitian dapat dideskripsikan bahwa berdasarkan Surat Perjanjian Pengelolaan, bertujuan untuk pengelolaan kolam renang secara efektif oleh PIHAK KEDUA untuk memenuhi kebutuhan masyarakat Kabupaten Banyumas berupa fasilitas kolam renang yang baik. Dengan demikian tujuan bersama tersebut dapat dikatakan untuk mengadakan suatu hubungan hukum, hal tersebut tidaklah bertentangan dengan Pasal 1357 KUH Perdata.

Bahwa Surat Perjanjian sebagaimana diatur dalam Peraturan Daerah Kabupaten Daerah Tingkat II Banyumas Nomor 3 Tahun 1988 tentang Penyertaan Modal Daerah pada Pihak Ketiga, dengan tidak bertentangan dengan Pasal 1337 KUH Perdata, yang menentukan suatu sebab adalah terlarang apabila dilarang undang-undang atau apabila berlawanan dengan kesusilaan atau ketertiban umum.

Perjanjian pengelolaan kolam renang langen tirta kembar antara Pemerintah Kabupaten Banyumas dengan PT Graha Cipta Guna telah memenuhi syarat sahnya kontrak berdasarkan Pasal 1320 KUH Perdata, baik syarat Subjektif maupun syarat Objektif maka, hal berikutnya yang harus diperhatikan adalah unsur essensialia dan kausa kontrak dari kontrak tersebut.

Berdasarkan perkembangan doktrin ilmu hukum dikenal adanya tiga unsur dalam perjanjian, antara lain : unsur essensialia, unsur natu- 
ralia, dan unsur accidentalia. Untuk mengetahui konstruksi hukum perjanjian maka yang diperlukan adalah unsur essensialia suatu perjanjian. Unsur essensialia adalah unsur mutlak, dimana tanpa adanya unsur tersebut tersebut perjanjian tidak mungkin ada. Jadi dapat dikatakan bahwa unsur essensialia adalah sesuatu yang harus ada, yang merupakan hal pokok sebagai syarat yang tidak boleh diabaikan dan harus dicantumkan dalam suatu perjanjian.Unsur Essensialia Perjanjian Pengelolaan Kolam Renang Langen Tirta Kembar terdapat 2 (dua) unsur essensialia yaitu yang pertama adalah kewajiban Pemerintah Kabupaten Banyumas yang memiliki Kolam Renang tersebut harus menyediakan kolam renang beserta air dan PT Graha berkewajiban mengelola kolam renang tersebut dengan memberikan uang kontribusi sebesar Rp 10.000.000,- (sepuluh juta rupiah) setiap bulan. Kedua, Pemerintah Kabupaten Banyumas harus menyediakan lahan yang akan dibangun tribune dan sarana lain di sekitar kolam renang langen tirta kembar dan PT Graha Cipta Guna berkewajiban membangun tribun dan sarana kolam renang senilai Rp 500.000.000,- (lima ratus juta rupiah) setelah pembangunan tersebut selesai bangunan tersebut tetap digunakan dalam hal ini untuk pengelolaan kolam renang setelah jangka waktu perjanjian selesai, bangunan tersebut menjadi milik Pemerintah Kabupaten Banyumas, perjanjian tersebut disebut dengan perjanjian Bangun Guna Serah.

Unsur naturalia merupakan bagian-bagian isi perjanjian yang secara umum patut dan adil bagi para pihak karena merupakan konsekuensi logis dari perjanjian yang bersangkutan. Unsur naturalia ini oleh Undang -undang diatur dengan hukum yang bersifat mengatur atau menambah (regelend recht atau aanvullend recht). Unsur Naturalia pada Perjanjian Pengelolaan Kolam Renang Langen Tirta Kembar yaitu asas-asas yang berlaku sebagaimana ketentuan Bab I, Bab II dan Bab IV Buku III KUH Perdata.

Berdasarkan hasil penelitian, mengenai bea masuk kolam renang yang ditetapkan oleh Keputusan Bupati merupakan unsur perjanjian accidentalia. Unsur accidentalia adalah unsur perjanjian yang ditambahkan oleh para pihak karena undang-undang tidak mengatur tentang hal tersebut. Semua janji-janji dalam suatu perjanjian yang sengaja dibuat untuk menyimpangi ketentuan hukum yang mengatur atau menambah (regelend recht atau aanvullend recht) merupakan unsur accidentalia. Pemahaman tentang unsur accidentalia ini diartikan bahwa didalam suatu perjanjian apabila didalamnya undang-undang tidak mengaturnya maka para pihak dapat mengaturnya sendiri. Dengan demikian unsur accidentalia ini dapat berupa janji-janji yang dibuat oleh para pihak dalam hal mereka menyimpangi ketentuan yang bersifat menambah tersebut. ${ }^{14}$

Subjek Hukum dalam Perjanjian tersebut adalah Badan Hukum, Pemerintah Kabupaten Banyumas sebagai Badan Hukum Publik dan PT Graha Cipta Guna sebagai Badan Hukum Privat. Menurut Teori Badan Hukum terdapat beberapa teori , dapat dihimpun dalam dua golongan yaitu teori yang berusaha ke arah peniadaan persoalan badan hukum dan teori yang hendak mempertahankan persoalan badan hukum.

Pada Perjanjian Pengelolaan, teori badan hukum yang tepat adalah Teori Orgaan, karena dalam perjanjian ini terdapat dua badan hukum

14 Ahmad Miru, 2007, Hukum Kontrak dan Perancangan Kontrak, Jakarta :Raja Grafindo Persada hlm 31-32 
yaitu privat dan publik, menurut teori orgaan badan hukum seperti orang cakap dapat melakukan perbuatan hukum. Apabila menggunakan teori fiksi tidak tepat karena hanya badan hukum publik yang dapat melakukan perbuatan hukum sedangkan dalam perjanjian ini salah satu pihaknya adalah Badan Hukum Privat yaitu PT Graha Cipta Guna, dalam hal ini badan hukum privat tersebut cakap untuk melakukan perbuatan hukum.

Perjanjian Pengelolaan Kolam Renang Langen Tirta Kembar antara Pemerintah Kabupaten Banyumas dengan PT Graha Cipta Guna dapat dideskripsikan konstruksi hukum perjanjiannya disebut sebagai Perjanjian Tidak Bernama , perjanjian yang tidak diberi nama dan pengaturannya secara khusus dalam $\mathrm{KUH}$ Perdata namun ketentuan umum Perjanjian tetap berlaku yaitu ketentuan umum pada Bab I, Bab II dan Bab IV Buku III KUH Perdata.

\section{Penyelesaian Masalah}

Perjanjian antara Pemerintah Kabupaten Banyumas dengan PT Graha Cipta Guna telah menimbulkan permasalahan pada saat pelaksanaan perjanjian. Pengelolaan Kolam Renang Langen Tirta Kembar sejak tahun 2006 Pihak Pengelola PT Graha Cipta Guna tidak dapat melaksanakan pengelolaan kolam renang karena mata air berikut bak penampung dan pipa penyalur air milik Pemerintah Kabupaten Banyumas yang menjadi suplai air kolam renang ditutup warga Kelurahan Sumampir, Kecamatan Purwokerto Utara. Sejak tanggal 25 Juni Tahun 2007 Kolam Renang Langen Tirta Kembar ditutup karena permasalahan air yang buruk dan dapat membahayakan kesehatan yang dapat mengakibatkan penyakit kulit pada masyarakat pengunjung kolam renang tersebut. Sejak tahun
2007 hingga tahun 2009 tidak ada upaya perbaikan kolam renang tersebut sehingga kolam renang langen tirta kembar menjadi mangkrak dan tidak beroperasional kembali hingga saat ini Tahun 2015, oleh karena permasalahan tersebut PT Graha Cipta Guna mengajukan gugatan pada Pengadilan Negeri Purwokerto dan Pemerintah Kabupaten Banyumas sebagai Tergugat.

Dasar gugatan menyebutkan duduk permasalahan ada pada wanprestasi mengenai suplai air kolam renang langen tirta kembar yang ditutup oleh masyarakat sekitar kolam renang. Suplai air merupakan hal yang paling utama dalam pengelolaan kolam renang, sehingga dengan adanya permasalahan suplai air tersebut pihak pengelola yaitu PT Graha Cipta Guna tidak dapat melakukan pengelolaan kolam renang langen tirta kembar sejak tahun 2007.

Menurut Pertimbangan Hukum Hakim bahwa berdasarkan alat bukti yang ada tidak satupun dijumpai adanya klausul yang merupakan kewajiban PT Graha untuk menyediakan pengadaan air untuk Kolam Renang Langen Tirta Kembar. Berdasarkan pengakuan PT Graha Cipta Guna dan diakui oleh Pemerintah Kabupaten Banyumas bahwa air kolam renang sudah disediakan oleh Pemerintah Kabupaten Banyumas sejak awal pengelolaan yang berasal dari sumber mata air Ringin Tirta Kembar berada di lahan milik masyarakat dan disalurkan ke Kolam Renang Langen Tirta Kembar melalui saluran air yang melewati tanah-tanah milik masyarakat, sehingga pengertian Kolam Renang sebagai bagian dari bangunan Kolam Renang Langen Tirta Kembar sebagaimana tercantum dalam Pasal 1 Surat Perjanjian Nomor 106/ 1988 ataupun yang tercantum dalam Surat Perjanjian Nomor 20 Tahun 1993 sebagaimana telah di- 
rubah pada Perubahan Pertama tanggal 5 Febuari 2001, pada situasi dan kondisi saat perjanjian dibuat dapat ditafsirkan bahwa pengertian kolam renang berarti, kolam renang beserta dengan airnya atau dengan perkataan lain secara diam-diam telah disepakati oleh para pihak bahwa air untuk kolam renang ikut disepakati sebagai kewajiban dari Pemerintah Kabupaten Banyumas karena air tersebut termasuk bagian dari bangunan kolam renang Langen Tirta Kembar milik Pemerintah Kabupaten Banyumas yang dikelola PT Graha Cipta Guna.

Berdasarkan pengakuan Pemerintah Kabupaten Banyumas dalam jawaban gugatannya bahwa air kolam renang sudah disediakan oleh Pemerintah Kabupaten Banyumas sejak awal pengelolaan, maka menurut pertimbangan majelis hakim terhentinya suplai air untuk kolam renang langen tirta kembar berdasarkan asas kepatutan dan asas itikad baik dalam suatu perjanjian menjadi kewajiban / tanggung jawab Pemerintah Kabupaten Banyumas.

Penafsiran pengertian kolam renang dalam perjanjian a quo di dasarkan bahwa perjanjian tidak hanya mengikat untuk hal-hal yang dengan tegas dinyatakan di dalamnya, tetapi juga untuk segala sesuatu yang menurut sifat perjanjian diharuskan oleh kepatutan. Asas Kepatutan, sebagaimana disebutkan dalam Pasal 1339 KUH Perdata, suatu perjanjian tidak hanya mengikat untuk hal-hal yang dengan tegas dinyatakan di dalamnya, tetapi juga untuk segala sesuatu yang menurut sifat perjanjian, diharuskan oleh kepatutan, kebiasaan atau undangundang.
Berkaitan dengan permasalahan yang terjadi pada perjanjian pengelolaan kolam renang langen tirta kembar sebagaimana duduk perkara yang mendasarkan gugatan karena adanya wanprestasi. Wanprestasi adalah apabila dalam suatu perjanjian salah satu pihak tidak melaksanakan apa yang diperjanjikan, maka dapat dikatakan bahwa pihak tersebut wanprestasi atau ingkar janji. ${ }^{15}$

Pasal 1267 KUH Perdata menyebutkan, "Pihak terhadap siapa perikatan tidak dipenuhi, dapat memilih apakah ia, jika hal itu masih dapat dilakukan, akan memaksa pihak yang lain untuk memenuhi perjanjian, ataukah ia akan menuntut pembatalan perjanjian, disertai penggantian biaya kerugian dan bunga." Apabila salah satu pihak wanprestasi, maka pihak yang dirugikan maka dapat menuntut Pihak yang melakukan wanprestasi untuk memenuhi atau melaksanakan perjanjian, pembatalah perjanjian, biaya ganti kerugian, pelaksanaan perjanjian disertai dengan biaya ganti kerugian, pembatalan perjanjian dan biaya ganti kerugian.

Berdasarkan amar putusan Mahkamah Agung berupa penolakan permohonan kasasi dari Pemohon Kasasi. Sehingga putusan Pengadilan Negeri Purwokerto dikuatkan lagi dan pemerintah dalam hal ini harus melaksanakan putusan pengadilan atau disebut dengan ekseskusi. Hal yang cukup memberatkan adalah penggantian uang hasil pengelolaan yaitu berupa kerugian materiil sebagaimana disebutkan dalam hasil penelitian nomor 2.4 huruf c poin 10 , menghukum Pemerintah Kabupaten Banyumas untuk membayar Rp 260.000.000,(dua ratus enam puluh juta rupiah dan

15 Mariam Darus Badrulzaman, 2011, KUH Perdata Buku III Hukum Perikatan dengan Penjelasan, Bandung : Alumni, hlm 22-23 
membayar uang paksa (dwangsom) kepada Penggugat sebesar Rp 1.000.000,- (satu juta rupiah) setiap hari terhitung sejak putusan ini mempunyai kekuatan hukum tetap (inkracht van gewijsde verklaaring) sampai dengan Pemerintah melaksanakan putusan ini (eksekusi). Putusan mempunyai kekuatan hukum tetap sebagaimana putusan kasasi tertanggal 14 Juli 2011.

Penyelesaian masalah pada tingkat peradilan tersebut sudah mempunyai kekuatan hukum yang tetap (inkracht), setelah selesai pada tahap peradilan selanjutnya adalah pelaksanaan dari eksekusi tersebut, dalam hal ini Pemerintah Kabupaten Banyumas diwajibkan untuk melaksanakan eksekusi sebagaimana amar Putusan Pengadilan Negeri Purwokerto yaitu berupa pelaksanaan perjanjian dan ganti rugi sejumlah uang serta dwangsom (uang paksa) pada PT Graha Cipta Guna.

Kewajiban Pemerintah Kabupaten Banyumas untuk menjalankan eksekusi putusan berupa pembayaran sejumlah uang untuk ganti rugi dan uang paksa (dwangsom), maka pemerintah harus menganggarkan pada Anggaran Pendapatan dan Belanja Daerah (APBD), karena pemerintah sebagai badan hukum publik pengelolaan uang harus dianggarkan melalui APBD dalam hal ini kebijakan dari Bupati Kabupaten Banyumas sebagai Kepala Pemerintahan untuk menganggarkan dana berupa ganti rugi dan uang paksa (dwangsom) untuk pelaksanaan eksekusi pembayaran tesrsebut.

Adanya penganggaran dana pada Rancangan APBD (RAPBD) terkait dengan Kebijakan publik, kebijakan publik adalah kebijakankebijakan yang dibuat oleh pemerintah sebagai

16 Abdul Halim dan lcuk Rangga Bawono, 2011, Pengelolaan Keuangan Negara dan Daerah : Hukum, Kerugian pembuat kebijakan untuk mencapai tujuan-tujuan tertentu di masyarakat dimana dalam penyusunannya melalui berbagai tahapan. Tahap perencanaan APBD merupakan tahapan penyusunan dan penetapan APBD itu sendiri.Tahap penyusunan didasarkan pada rencana kerja pemerintah yang akan dihasilkan Rancangan APBD, rancangan tersebut selanjutnya diajukan ke DPRD untuk dibahas dan disetujui. ${ }^{16}$ Rancangan APBD yang diusulkan oleh Bupati sebagai Eksekutif harus mendapatkan persetujuan dari DPRD Kabupaten Banyumas sebagai pihak Legislatif, baru dapat terlaksana eksekusi berupa pembayaran sejumlah uang apabila Rancangan APBD tersebut telah disahkan antara Eksekutif dan Legislatif menjadi APBD.

Penyelesaian masalah Pengelolaan Kolam Renang Langen Tirta Kembar yaitu berupa pelaksanaan Putusan Pengadilan (eksekusi) berupa penambahan jangka waktu pengelolaan selama 26 (dua puluh enam) bulan dan pembayaran ganti kerugian $\mathrm{Rp} 260.000 .000$,(dua ratus enam puluh juta rupiah) serta uang paksa Rp 1.000.000,- (satu juta rupiah) per hari. Oleh karena penganggaran dana ganti rugi atas putusan pengadilan baru di anggarkan pada tahun 2015 , maka uang paksa (dwangsom) yang dihitung per hari semakin hari semakin bertambah dan maka berdasarkan hasil penelitian nomor 3.4 total pada Febuari 2015 Pemerintah membayarkan Rp 1.400.000.000,- (satu milyar empat ratus juta rupiah).

\section{PENUTUP}

\section{Simpulan}

Perjanjian Pengelolaan Kolam Renang Langen Tirta Kembar merupakan Kontrak

Negara dan Badan Pemeriksa Keuangan, Yogyakarta : Upp Stim Ykpn, hlm 2 
Pemerintah yang termasuk pada jenis Perjanjian tidak bernama. Perjanjian Pengelolaan Kolam Renang Langen Tirta Kembar tersebut merupakan kontrak bagi keuntungan sebagaimana penjelasan Peraturan Menteri Dalam Negeri Nomor 3 Tahun 1986 tentang Penyertaan Modal Daerah Pada Pihak Ketiga, Perjanjian ini merupakan jenis perjanjian tidak bernama yang tunduk pada ketentuan umum Bab I, II dan IV Buku III KUH Perdata.

Penyelesaian masalah melalui jalur Peradilan, Putusan Pengadilan Negeri Purwokerto mengabulkan gugatan PT Graha Cipta Guna atas dasar wanprestasi. Putusan Pengadilan Tinggi dan Putusan Kasasi Mahkamah Agung menguatkan Putusan Pengadilan Negeri, Mahkamah Agung menolak permohonan kasasi dari pihak Pemerintah Kabupaten Banyumas, dalam penyelesaian kasus ini pemerintah telah terbukti wanprestasi maka Pemerintah harus melaksanakan eksekusi putusan tersebut yaitu berupa pelaksanaan perjanjian dan ganti kerugian. Pelaksanaan perjanjian dengan penambahan jangka waktu pengelolaan selama 26 (dua puluh enam) bulan dan pembayaran kerugian materiil sebesar $\mathrm{Rp}$ 260.000.000,- (dua ratus enam puluh juta rupiah) serta uang paksa (dwangsom) Rp 1.000.000,(satu juta rupiah) per hari.

\section{Saran}

Penulis berpendapat bahwa dengan adanya Putusan Kasasi Mahkamah Agung maka Pemerintah Kabupaten Banyumas dan PT Graha Cipta Guna harus mengadakan perubahan perjanjian atau addendum, karena dalam amar putusan pengadilan menyebutkan bahwa jangka waktu pengelolaan kolam renang langen tirta kembar diperpanjang menjadi 26 (dua puluh enam) bulan maka berlaku ketentuan Peraturan Pemerintah yang baru yaitu Peraturan Pemerintah Nomor 27 Tahun 2014 tentang PengeIolaan Barang Milik Negara / Daerah.

\section{DAFTAR PUSTAKA}

Ali, Chidir. 2014. Badan Hukum. Bandung : Alumni

Badrulzaman,Mariam Darus. 2011. Aneka Hukum Bisnis. Bandung : Alumni

2011. KUH Perdata Buku III Hukum Perikatan dengan Penjelasan. Bandung : Alumni

Fuady, Munir. 2014. Konsep Hukum Perdata. Jakarta : Raja Grafindo Persada

Halim, Abdul dan Icuk Rangga Bawono. 2011. Pengelolaan Keuangan Negara dan Daerah : Hukum, Kerugian Negara dan Badan Pemeriksa Keuangan. Yogyakarta : Upp Stim Ykpn

Ibrahim, Johnny. 2005. Teori dan Metodelogi Penelitian Hukum Normatif. Malang : Bayumedia

Marzuki, Peter Mahmud. 2005. Penelitian Hukum Normatif. Jakarta : Kencana

Miru, Ahmad. 2007. Hukum Kontrak dan Perancangan Kontrak. Jakarta : Raja Grafindo Persada

Muhammad, Abdul Kadir. 1982. Hukum Perikatan. Bandung : Alumni

Pangaribuan, Oktavia Ester dan Sumini Widyaiswara Muda. 2010. Modul Pokokpokok Pengelolaan Barang Milik Daerah. Tanpa Kota : Pusdiklat Kekayaan Negara dan Perimbangan Keuangan

Rahardjo, Satjipto. 1986. IImu Hukum. Bandung : Alumni

Satrio, J. 2001. Hukum Perikatan, Perikatan Yang Lahir Dari Perjanjian Buku II. Bandung : Citra Aditya Bakti

Scholten, Paul. 1992. Mr. C. Asser, Penuntun Dalam Mempelajari Hukum Perdata Belanda, Bagian Umum. Yogyakarta : Gajah Mada University Press

Soekanto, Soerjono dan Sri Mamudji, 2007. Penelitian Hukum Normatif. Jakarta : PT Raja Grafindo Persada 
Subekti, R. 1987. Hukum Perjanjian. Jakarta : Intermasa

Sumitro, Ronny Hanitijo. 2007. Metode Penelitian Hukum dan Jurimetri. Jakarta : PT Raja Grafindo Persada

Tjandra, W.Riawan. 2014. Hukum Sarana Pemerintahan. Yogyakarta : Cahaya Atma Pustaka

Waluyo, Bambang. 1985. Penelitian Hukum Dalam Praktek. Jakarta : PT Raja Grafindo Persada 